\title{
Skeletal cryptococcosis: Case report and review of the literature
}

\author{
LORI WOOD MD, LIL MIEDZINSKI MD FRCPC
}

\begin{abstract}
L WOOD, L MIEDZINSKI. Skeletal cryptococcosis: Case report and review of the literature. Can J Infect Dis $1996 ; 7(2): 125-133$. A case of isolated cryptococcal skull infection is presented in a patient with unexplained CD4 lymphopenia and chronic hepatitis B. All cases of this disease reported in the English literature from 1956 to the present are reviewed. The literature suggests that skeletal cryptococcosis is manifested in only $5 \%$ to $10 \%$ of recognized cases of disseminated cryptococcosis and that isolated skeletal disease without evidence of other tissue involvement is even less common. When isolated bony disease does occur it tends to occur in immunocompromised hosts, particularly those with defects of cell mediated immunity. Any bony site can be involved, most commonly the vertebrae, with the presentation often being a soft tissue swelling and pain in the affected area. Systemic constitutional symptoms occur in a minority of patients. Radiographic investigations are nonspecific and the gold standard of diagnosis remains culture isolation from bone tissue. The most commonly employed therapy for isolated bone disease is amphotericin alone or combined with surgical debridement. The new azoles may have a role in future therapy.
\end{abstract}

Key Words: Bone infection, Cryptococcus, Fluconazole, Osteomyelitis, Skeletal infection

\section{Cryptococcose squelettique : rapport de cas et survol de la littérature}

RÉSUMÉ : Un cas isolé d'infection crânienne cryptococcique est présenté chez un patient présentant une lymphopénie des CD4 et une hépatite chronique B inexpliquées. Tous les cas de ce type de maladie signalés dans la littérature de langue anglaise de 1956 jusqu'à nos jours ont été passés en revue. Selon la littérature, la cryptococcose squelettique se manifeste chez $5 \%$ à $8 \%$ seulement des cas reconnus de cryptococcose disséminée et cette maladie squelettique isolée, sans autre atteinte tissulaire est encore moins fréquente. Lorsqu'une maladie osseuse isolée se manifeste, elle tend à survenir chez des hôtes immunodéprimés, particulièrement chez ceux qui présentent des anomalies de l'immunité à médiation cellulaire. Tout siège osseux peut être affecté, les plus fréquents étant les vertèbres et le tableau se compose souvent d'une enflure des tissus mous et d'une douleur au siège de l'infection. Les symptômes systémiques se manifestent chez une minorité de patients. Les examens radiologiques ne sont pas spécifiques et la norme diagnostique demeure la culture de tissu osseux. Le traitement le plus souvent employé dans les cas de maladies osseuses isolées est l'amphotéricine seule ou en association avec un débridement chirurgical. Les nouveaux médicaments de type azole pourraient exercer un rôle dans le traitement futur.

Division of Infectious Diseases, University of Alberta Hospitals, Edmonton, Alberta

Correspondence and reprints: Dr L Miedzinski, Division of Infectious Diseases, 2E4.11 Walter Mackenzie Health Sciences Center, University of Alberta Hospitals, Edmonton, Alberta T6G 2B7. Telephone 403-492-7313, fax 403-492-7137, e-mail lil@nshade.uah.ualberta.ca

Received for publication June 16, 1995. Accepted November 22, 1995 
C ryptococcus neoformans is a ubiquitous fungus that most commonly causes infection involving the lungs and central nervous system. It rarely causes skeletal infection in humans, but when it does, it tends to affect immunocompromised hosts with obvious disease processes or laboratory detected immunological abnormalities. Given the substantial increase of immunocompromised hosts as a consequence of malignancies, transplantation and their respective therapies, the frequency of invasive fungal infections has risen and will likely continue to do so. We present a case of isolated cryptococcal skeletal infection, review the literature related to this topic and summarize the reported cases in the English literature of isolated skeletal cryptococcal disease from 1956, when amphotericin became available, to August 1995.

\section{CASE PRESENTATION}

A 49-year-old Chinese male cook presented in January 1994 with headache, initially localized to the superior aspect of his skull but later lateralized to the left. It was described as sharp, dull and throbbing at different times. By February 1994 the headache was waking him at night and requiring regular acetaminophen with only partial pain relief. Over a three-week period, he developed a tender, fluctuant, left temporal mass with no associated induration, erythema or discharge. No other neurological or constitutional symptoms such as fever, weight loss or night sweats were present. Of note, the patient had exposure to pigeons when visiting Hong Kong in the year before his diagnosis.

Significant past medical history included chronic hepatitis B most likely acquired by vertical transmission and first documented in 1988. He had been referred to the Hepatology Clinic at the University of Alberta Hospitals for enrolment in a trial of an investigational antiviral agent, 3TC, which was started November 16, 1993. The agent was discontinued February 24, 1994 to establish whether it might be contributing to the patient's symptomatology.

Out-patient investigations included plain x-ray of the skull, nuclear medicine bone scan and a nonaugmented computed tomography scan of the head. These identified a single bony lytic lesion in the left temporal area with corresponding soft tissue swelling, a focal area of increased uptake in the same area (Figure 1) and major destructive changes in the left temporal area (Figure 2).

The patient was admitted April 10, 1994 for elective excision of the bony lesion. The differential diagnosis was extensive and included malignancy, infection, and benign epidermoid or dermoid cyst. A white blood cell count was $9.2 \times 10^{6}$ cells/L with $84 \%$ neutrophils, $8 \%$ lymphocytes, $6 \%$ monocytes and $1 \%$ eosinophils. The patient had a normal chest x-ray. At surgery, a subgaleal and epidural collection of purulent material was found, incised and drained. The material was submitted for pathology examination, routine culture and sensitivity, as well as mycobacterial and fungal stains and culture.

Material from the lesion showed yeast-like organisms on direct mycological examination using periodic acid-Schiff stain, the typical appearance of $\mathrm{C}$ neoformans on India ink

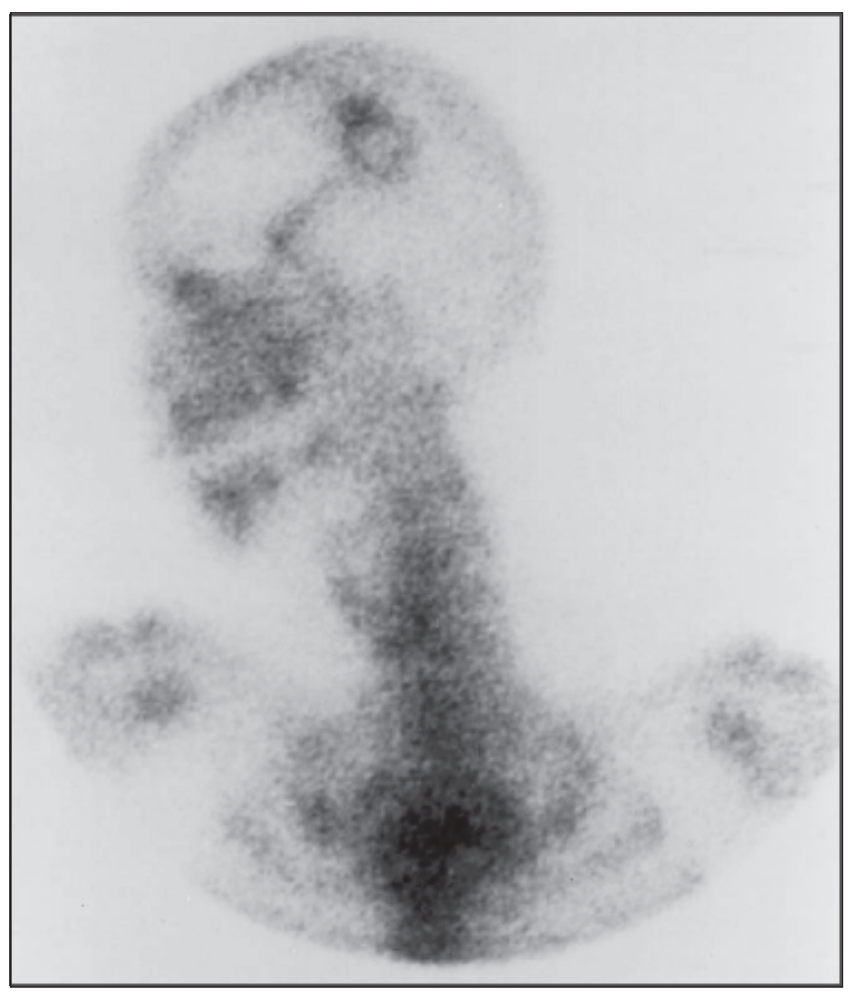

Figure 1) Technetium-99m methylene diphosphanate bone scan. An area of increased uptake in the left temporal bone corresponding to a lytic lesion on plain skull film is shown

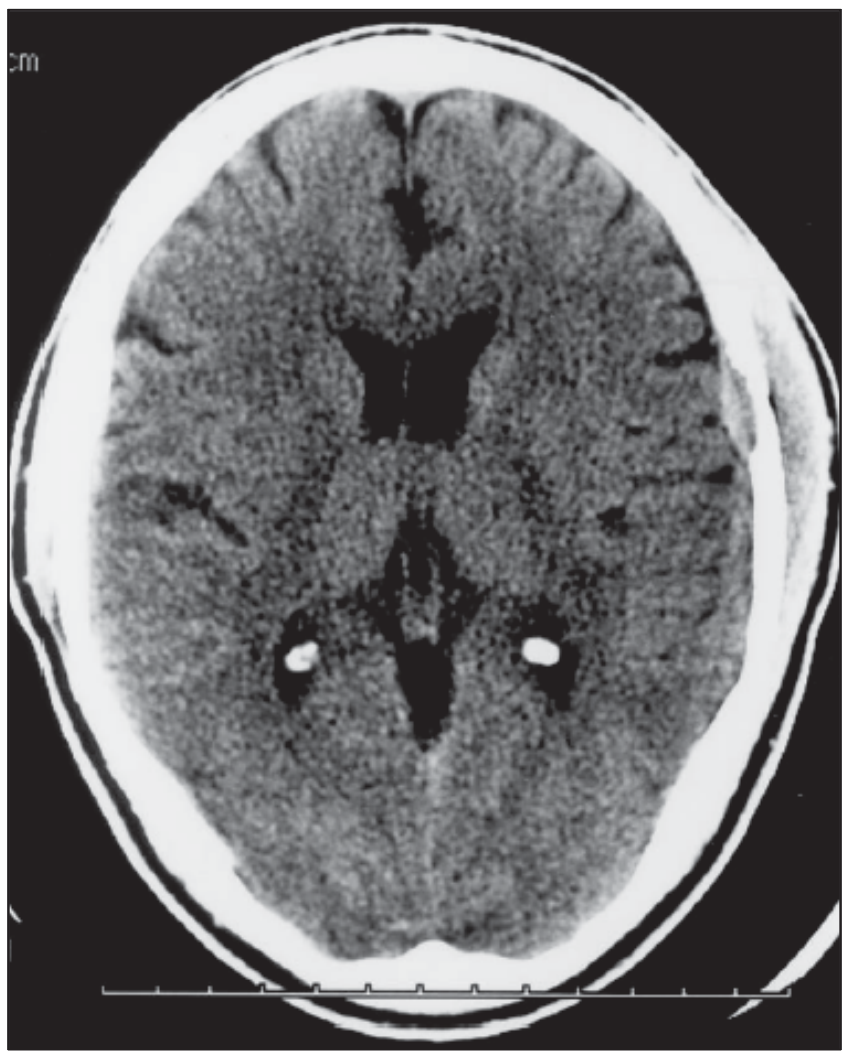

Figure 2) Nonaugmented computed tomography of the head. Destructive changes in the left temporal bone with associated soft tissue swelling and a subgaleal collection are shown 
stain, and was positive for cryptococcal antigen using a Wampole latex agglutination test (International Biological Labs, Inc, New Jersey). Subsequently C neoformans was isolated on phytone yeast extract agar culture media. Further investigations for evidence of disseminated cryptococcal disease included a lumbar puncture, which was negative on India ink stain and negative for cryptococcal antigen. Blood and cerebrospinal fluid (CSF) fungal cultures were also negative.

The patient was diagnosed with cryptococcal skeletal infection of the skull with no other evidence of disease. Because cryptococcosis does not usually occur in immunocompetent hosts, an underlying predisposing condition was investigated. Human immunodeficiency virus (HIV) serotesting was negative on four occasions including a search for p24 core antigen by enzyme immunoassay. Serum immunoglobulin levels were normal. Delayed hypersensitivity skin testing showed a positive reaction to five tuberculin units. However, bloodwork was significantly abnormal in showing a marked CD4 lymphopenia with an absolute count of $0.15 \times 10^{9}$ cells/L. Repeat estimates demonstrated counts less than $0.2 \times 10^{9}$ on four estimates over an 18-month period. An explanation for this remains obscure. Serotesting for human T cell leukemia virus (HTLV) -I and HTLV-II was also negative.

The patient was started on intravenous amphotericin B and received a total dose of $300 \mathrm{mg}$ over eight days. Over this time his creatinine rose from a baseline of $107 \mu \mathrm{mol}$ to $158 \mu \mathrm{mol}$, correlating with a measured $24 \mathrm{~h}$ creatinine clearance of $49 \mathrm{~mL} / \mathrm{min} / 1.7 \mathrm{~m}^{2}$. Therapy was changed to oral fluconazole $200 \mathrm{mg} / \mathrm{day}$, which he continued for six months with progressive clinical improvement. A nuclear medicine immunoglobulin scan on May 2, 1994 was interpreted as a normal postoperative scan, and a bone scan on July 19, 1995 revealed no active osteomyelitis and only changes consistent with postoperative status.

Unlike for other patients with CD4 lymphopenia due to AIDS who usually remain on lifelong antifungal therapy after documented cryptococcal disease, it was decided to discontinue fluconazole after six months and to observe the patient. $\mathrm{He}$ is receiving prophylaxis against Pneumocystis carinii pneumonia in the form of daily cotrimoxazole and remains clinically well 18 months after his diagnosis and treatment.

\section{LITERATURE REVIEW}

$C$ neoformans is an encapsulated, spherical fungus that reproduces by budding and is recognized to have worldwide distribution. It can produce disease in both immunocompetent and immunocompromised hosts, most commonly affecting the pulmonary and central nervous systems where it can cause an acute, subacute, or chronic infection. The portal of entry is via inhalation of airborne particles, with bird droppings and associated soil being the major environmental source. The true incidence of pulmonary cryptococcal infections is not known because disease can be asymptomatic or associated with vague, nonspecific symptoms. It often resolves spontaneously and requires no treatment in immunocompetent hosts. Kerkering et al (1) reviewed all cases of cryptococcal infections evaluated at the Medical College of Virginia Hospitals over a 14-year period from 1966 to 1980. A total of 93 patients with cryptococcal infections were identified, with pulmonary involvement clinically present in $12.9 \%$ of patients, central nervous system (CNS) involvement in $55.9 \%$, and combined pulmonary and CNS involvement in $31.2 \%$. The phrase 'clinically involved' is relevant because Lewis and Rabinovich (2) reported $45 \%$ of patients with clinical CNS disease had lung involvement on autopsy that was not recognized ante-mortem. CNS infection most commonly involves the leptomeninges but may also include cerebral, intraventricular and spinal cord granulomas $(1,3)$.

Skeletal cryptococcal infections are a very uncommon manifestation of disseminated cryptococcal disease occurring in only $5 \%$ to $10 \%$ of patients with disseminated disease $(4,5)$, with isolated skeletal cryptococcal infections occurring even less commonly. It is felt that most skeletal cryptococcal infections arise secondary to hematogenous spread from a primary pulmonary infection. Other potential sources are bony trauma, embolic phenomenon, contiguous skin infection or contiguous neural infection (6). Any bony site may be involved, with the most commonly reported being vertebrae, pelvis and ribs. The disease may occur at a single site or multiple sites $(7,8)$.

Isolated skeletal cryptococcal disease such as in the case presented is very uncommon. To gain a better understanding of this disease entity, the involved sites, treatment and outcome, a comprehensive search for all published case reports of isolated skeletal cryptococcal disease was undertaken. A MEDLINE search was done of the English-language literature published from 1966 through August 1995 using the terms 'cryptococcus', 'osteomyelitis', 'bone' and 'skeletal'. A manual search was then done for other contributions during this time as well as of the literature published from 1956 through 1966. Forty-five cases including the present case were found and are listed in Table 1. Cases were excluded if they reported positive culture, stain, or histology of other tissues or organs such as cutaneous lesions $(6,9)$, CSF involvement $(10,11)$, sputum $(12,13)$, joint involvement (14-16) or chest x-ray abnormalities that improved with antifungal therapy $(17,18)$. Patients with soft tissue collections or abscesses adjacent to the involved bone were included in this series. In cases that did not mention investigations for disseminated disease, it has been assumed that the patients had isolated disease, and they have been included in this review.

It can be seen from the 45 identified cases that isolated cryptococcal skeletal infection can occur in any age group, and can range from an incidental radiological finding to a systemic disease with local and constitutional signs and symptoms. Sixty-two per cent (28 of 45) of patients had one site involved, whereas $38 \%$ (17 of 45 ) had more than one site involved. In these 45 cases, 80 bony sites were involved, with the most frequent being the vertebrae in $29 \%$ ( 23 of 80 ), the ribs in $11 \%$ (nine of 80 ), tibia in 10\% (eight of 80 ) and femur in 9\% (seven of 80 ). The most commonly described clinical presentation was soft tissue swelling and pain of variable duration ranging from an acute presentation to 33 months. Fever was not a 
TABLE 1

Summary of 45 cases of isolated skeletal cryptococcosis from 1956 to 1995

\begin{tabular}{|c|c|c|c|c|c|}
\hline Case/Ref & Age/Sex & Bony site involved & Predisposing factor(s) & Treatment & Outcome \\
\hline $1 / 3$ & $71 \mathrm{M}$ & Frontal bone & $\begin{array}{l}\text { CLL } \\
\text { Immunosuppressive drugs }\end{array}$ & $\begin{array}{l}\text { Debridement } \\
\text { Ampho }\end{array}$ & "did well" \\
\hline $2 / 4$ & $23 \mathrm{M}$ & Rib 8 & $\begin{array}{l}\text { Sarcoidosis } \\
\text { steroids }\end{array}$ & $5 \mathrm{FC} \times 6$ weeks & $\begin{array}{l}\text { Well at } 40 \text { months; no evi- } \\
\text { dence of x-ray disease }\end{array}$ \\
\hline $3 / 7$ & $40 \mathrm{~F}$ & Ulna & $\begin{array}{l}\text { Sarcoidosis; CMI abnor- } \\
\text { malities on lab tests }\end{array}$ & Curettage & Asymptomatic at 5 weeks \\
\hline $4 / 7$ & $68 \mathrm{M}$ & Scapula & $\begin{array}{l}\text { CMI abnormalities on lab } \\
\text { tests }\end{array}$ & Ampho (1000 mg) & $\begin{array}{l}\text { Acute renal failure } 2 \\
\text { ampho; well at } 4 \text { years }\end{array}$ \\
\hline $5 / 7,47$ & $15 \mathrm{M}$ & Distal humerus & None noted & Ampho (395 mg) & $\begin{array}{l}\text { Died at } 2 \text { years with TB, } \\
\text { hepatitis and pneumonia; } \\
\text { elbow normal at autopsy }\end{array}$ \\
\hline $6 / 18$ & $9 M$ & Proximal tibia & None noted & Ampho (1500 mg) & $\begin{array}{l}\text { Well at } 2 \text { years; } x \text {-ray reso- } \\
\text { lution }\end{array}$ \\
\hline $7 / 18$ & $18 \mathrm{M}$ & Proximal tibia & None noted & Ampho (1500 mg) & $\begin{array}{l}\text { Well at } 2 \text { years; } x \text {-ray reso- } \\
\text { lution }\end{array}$ \\
\hline $8 / 19$ & $84 \mathrm{M}$ & $\begin{array}{l}\text { Rib, T10, T11, sa- } \\
\text { crum, femur }\end{array}$ & $\begin{array}{l}\text { DM; lung cancer } \\
\text { (at autopsy) }\end{array}$ & None & Diagnosed at autopsy \\
\hline $9 / 20$ & $35 \mathrm{~F}$ & Distal tibia & None noted & Curettage & \\
\hline $10 / 21$ & $50 M$ & T9, T10, T11 & $\begin{array}{l}\text { None noted } \\
\text { (chronic hepatitis) }\end{array}$ & $\begin{array}{l}\text { Curettage } \times 2 \\
\text { ampho }(1105 \mathrm{mg}) \\
\text { 5FC (2202 mg) }\end{array}$ & $\begin{array}{l}\text { No sign of infection at } \\
2 \text { years; disabled but } \\
\text { working at previous job }\end{array}$ \\
\hline $11 / 22$ & $33 \mathrm{M}$ & $\begin{array}{l}\text { 5th costosternal } \\
\text { junction }\end{array}$ & None noted & $\begin{array}{l}\text { Excision } \\
\text { ampho (480 mg) }\end{array}$ & Well at 29 months \\
\hline $12 / 44$ & $54 \mathrm{M}$ & $\begin{array}{l}\text { Calcaneus; distal } \\
\text { tibia; ulna - bilat- } \\
\text { eral }\end{array}$ & $\begin{array}{l}\text { Squamous cell cancer; } \\
\text { CMI abnormalities on } \\
\text { lab tests }\end{array}$ & $\begin{array}{l}\text { Curettage calcaneus/tibia } \\
\text { ampho - D/C } 2 \text { toxicity } \\
\text { 5FC }(2700 \mathrm{~g})\end{array}$ & $\begin{array}{l}\text { x-rays improved; died } \\
2 \text { years later of cancer }\end{array}$ \\
\hline $13 / 45,48$ & $10 \mathrm{M}$ & Scapula & $\begin{array}{l}\text { IL-2 deficiency } \\
\text { HIV negative }\end{array}$ & Ampho/5FC $\times 3$ months & $\begin{array}{l}\text { No evidence of disease at } 4 \\
\text { years }\end{array}$ \\
\hline $14 / 31$ & $33 \mathrm{M}$ & $\begin{array}{l}\text { Acromium } \\
\text { scapula }\end{array}$ & $\begin{array}{l}\text { Sarcoidosis } \\
\text { steroids }\end{array}$ & None & $\begin{array}{l}\text { Bone lesion culture positive } \\
\text { in retrospect; presented } \\
1 \text { year later with CNS dis- } \\
\text { ease; died } 32 \text { months af- } \\
\text { ter onset of bone disease; } \\
\text { died } 4 \text { months } \\
\text { after onset of CNS disease }\end{array}$ \\
\hline $15 / 33$ & $10 \mathrm{~F}$ & Parietal bone & $\begin{array}{l}\text { SLE } \\
\text { steroids }\end{array}$ & $\begin{array}{l}\text { Craniotomy; ampho; } \\
\text { 5FC }\end{array}$ & $\begin{array}{l}\text { Died day } 10 \text { postoperation } \\
\text { of bilateral pneumonia/ } \\
\text { respiratory failure; no } \\
\text { autopsy }\end{array}$ \\
\hline $16 / 32$ & $34 \mathrm{~F}$ & $\begin{array}{l}\text { T5, rib 5, paraspinal } \\
\text { abscess }\end{array}$ & Sarcoidosis & & $\begin{array}{l}\text { Died at open biopsy from } \\
\text { presumed PE }\end{array}$ \\
\hline $17 / 36$ & & Orbit & No mention & $\begin{array}{l}\text { Ampho } \times 2 \text { weeks } \\
\text { ketoconazole }\end{array}$ & Lost to follow-up \\
\hline $18 / 37$ & $58 \mathrm{M}$ & Proximal tibia & None noted & $\begin{array}{l}\text { Debridement; ampho/ } \\
\text { gentamicin (intralesional) } \\
\text { x } 4 \text { months; } \\
\text { ketoconazole (48 g) }\end{array}$ & $\begin{array}{l}\text { No evidence of disease at } 2 \\
\text { years }\end{array}$ \\
\hline $19 / 49$ & $5 \mathrm{~F}$ & Femur & None noted & Curettage & $\begin{array}{l}\text { x-rays improved; } \\
\text { asymptomatic at } 18 \\
\text { months }\end{array}$ \\
\hline $20 / 49$ & $29 F$ & Ileum - 2 lesions & None noted & $\begin{array}{l}\text { Excision } \\
\text { ampho/5FC x } 2 \text { days }\end{array}$ & Asymptomatic at 18 months \\
\hline $21 / 50$ & $63 \mathrm{~F}$ & $\begin{array}{l}\text { Distal humerus; pa- } \\
\text { rietooccipital bone }\end{array}$ & DM; sarcoidosis; steroids & Ampho & Unknown \\
\hline $22 / 51$ & $54 \mathrm{~F}$ & Clavicle & DM; HIV-negative & Ampho; 5FC & $\mathrm{x}$-ray improved at 10 months \\
\hline
\end{tabular}


TABLE 1 (cont'd)

\begin{tabular}{|c|c|c|c|c|c|}
\hline $23 / 52$ & $43 M$ & Mid tibia & $\begin{array}{l}\text { ?Sarcoidosis (on basis of } \\
\text { CXR) }\end{array}$ & $\begin{array}{l}\text { Curettage; potassium io- } \\
\text { dide } \times 2 \text { months }\end{array}$ & $\begin{array}{l}\text { x-rays improved at } 1 \text { year; } \\
\text { died } 2 \text { years later of un- } \\
\text { known cause }\end{array}$ \\
\hline $24 / 53$ & $17 \mathrm{M}$ & L1, rib 12 & $\begin{array}{l}\text { Open trauma to back } \\
8 \text { year previously }\end{array}$ & Excision; ampho (510 mg) & Well at 27 months \\
\hline $25 / 54$ & $11 \mathrm{~F}$ & Femur & $\begin{array}{l}\text { CMI abnormalities on lab } \\
\text { tests }\end{array}$ & $\begin{array}{l}\text { Curettage; ampho (93 mg) } \\
\text { 5FC x } 6 \text { weeks }\end{array}$ & $\begin{array}{l}\text { Well at } 4 \text { months; x-rays no } \\
\text { change }\end{array}$ \\
\hline $26 / 55$ & $24 \mathrm{~F}$ & $\begin{array}{l}\text { Ileum, sacrum, L4, L5, } \\
\text { tibia, humeri, clavi- } \\
\text { cle, ribs } 6 \text { and } 7\end{array}$ & $\begin{array}{l}\text { CMI abnormalities on lab } \\
\text { tests + pigeon exposure }\end{array}$ & Ampho (4 g) & $\begin{array}{l}\text { Well at } 30 \text { months; x-ray } \\
\text { resolution }\end{array}$ \\
\hline $27 / 56$ & $19 F$ & Calcaneus & Sarcoidosis & Ampho; 5FC & "good" response \\
\hline $28 / 57$ & $1 \mathrm{M}$ & $\mathrm{C} 2, \mathrm{C} 3$ & None noted & $\begin{array}{l}\text { Curettage; ampho } \\
\text { (134 mg); 5FC (73 g) }\end{array}$ & $\begin{array}{l}\text { Well at } 16 \text { months; x-ray } \\
\text { improvement }\end{array}$ \\
\hline $29 / 58$ & $71 \mathrm{M}$ & Rib 4 & Squamous cell cancer & Ampho; 5FC & Asymptomatic \\
\hline $30 / 59$ & $80 F$ & Rib 3; acromium & $\begin{array}{l}\text { DM; CMI abnormalities } \\
\text { on lab tests }\end{array}$ & Curettage; 5FC (284 g) & $\begin{array}{l}\text { Bone scan - no change at } 9 \\
\text { months; clinical resolution; } \\
\text { died of CAD at } 13 \text { months }\end{array}$ \\
\hline $31 / 60$ & $42 \mathrm{~F}$ & Clavicle, humerus & None noted & $\begin{array}{l}\text { Excision clavicle; curettage } \\
\text { humerus; } \\
\text { ampho (1500 mg) }\end{array}$ & $\begin{array}{l}\text { x-ray improvement at } \\
3 \text { months }\end{array}$ \\
\hline $32 / 61$ & $33 \mathrm{M}$ & Femur & None noted & Ampho & Improved at 3 years \\
\hline $33 / 62$ & $56 \mathrm{~F}$ & $\begin{array}{l}\text { 4th metatarsal; up- } \\
\text { per radius }\end{array}$ & None noted & $\begin{array}{l}\text { Excision x 2; ampho } \\
\quad(50-100 \mathrm{mg})\end{array}$ & Normal x-ray at 3 years \\
\hline $34 / 63$ & $73 \mathrm{~F}$ & Femur - fractured & DM & ORIF; ampho (975 mg) & $\begin{array}{l}\text { Well at } 20 \text { days, using } \\
\text { walker; x-ray improvement }\end{array}$ \\
\hline $35 / 64$ & $69 \mathrm{~F}$ & Tibia & Sarcoidosis & Ampho & $\begin{array}{l}\text { Died } 3 \text { months later of } \\
\text { MI/PE while still on treat- } \\
\text { ment }\end{array}$ \\
\hline $36 / 65$ & $13 \mathrm{~F}$ & Femur & $\begin{array}{l}\text { None noted; normal CMI } \\
\text { lab tests }\end{array}$ & $\begin{array}{l}\text { Ampho }(1321 \mathrm{mg}) \\
\text { 5FC } \times 1 \text { month }\end{array}$ & Asymptomatic at 2 years \\
\hline $37 / 66$ & $10 \mathrm{~F}$ & Ileum & $\begin{array}{l}\text { CMI abnormalities on lab } \\
\text { tests }\end{array}$ & $\begin{array}{l}\text { Ampho }(504 \mathrm{mg}) \\
\text { 5FC (224 g) }\end{array}$ & "did well" \\
\hline $38 / 67$ & $32 \mathrm{~F}$ & $\begin{array}{l}\text { Clavicle,T2, T3; } \\
\text { paravertebral ab- } \\
\text { scess }\end{array}$ & None noted & $\begin{array}{l}\text { Vertebral decompression; } \\
\text { ampho }\end{array}$ & $\begin{array}{l}\text { Lower limb weakness at } \\
4 \text { months }\end{array}$ \\
\hline $39 / 68$ & $24 M$ & Femur & None noted & $\begin{array}{l}\text { Curettage; ampho } \\
\text { (1000 mg) }\end{array}$ & $\begin{array}{l}\text { Well at } 6 \text { months; x-ray } \\
\text { resolution at } 2 \text { months }\end{array}$ \\
\hline $40 / 69$ & $26 M$ & $\begin{array}{l}\text { T5-8; paraspinal } \\
\text { mass }\end{array}$ & None noted & Ampho $\times 10$ weeks & $\begin{array}{l}\text { Well at } 1 \text { year; x-rays im- } \\
\text { proved }\end{array}$ \\
\hline $41 / 70$ & $44 \mathrm{~F}$ & $\begin{array}{l}\text { T4; soft tissue mass } \\
\text { between ribs } 3 \\
\text { and } 4\end{array}$ & Sarcoidosis & Ampho (1060 mg) & $\begin{array}{l}\text { Asymptomatic at } 11 \\
\text { months; } \\
\text { x-rays improved }\end{array}$ \\
\hline $42 / 71$ & $35 \mathrm{~F}$ & Humerus + abscess & Sarcoidosis & Ampho & x-ray improvement \\
\hline $43 / 72$ & 27 & $\begin{array}{l}\text { L2, L3; paraspinal } \\
\text { abscess }\end{array}$ & $\begin{array}{l}\text { None noted; T cell function } \\
\text { normal }\end{array}$ & $\begin{array}{l}\text { Ampho } \times 7 \text { weeks } \\
\text { 5FC } \times 7 \text { weeks }\end{array}$ & $\mathrm{x}$-rays improved at 7 weeks \\
\hline $44 / 73$ & $42 \mathrm{~F}$ & $\begin{array}{l}\text { T8-10; chest wall ab- } \\
\text { scess; paraverte- } \\
\text { bral, prevertebral, } \\
\text { epidural space col- } \\
\text { lections }\end{array}$ & $\begin{array}{l}\text { ?Sarcoidosis (on basis of } \\
\text { CXR); HIV-negative }\end{array}$ & Ampho & \\
\hline $\begin{array}{l}\text { 45/current } \\
\text { case }\end{array}$ & $49 M$ & Temporal bone & CD4 lymphopenia & $\begin{array}{l}\text { Debridement; ampho } \\
(300 \mathrm{mg}) \text {; fluconazole } \\
(36,000 \mathrm{mg})\end{array}$ & Asymptomatic at 18 months \\
\hline
\end{tabular}

Ampho amphotericin B; C Cervical; CAD Coronary artery disease; CLL Chronic lymphocytic leukemia; CMI Cell mediated immunity; CNS Central nervous system; CXR Chest x-ray; D/C Discontinued; DM Diabetes mellitus; 5FC Flucytosine; HIV Human immunodeficiency virus; IL-2 Interleukin-2; L Lumbar; MI Myocardial infarction; ORIF Open reduction and internal fixation; PE Pulmonary embolus; Ref Reference; SLE Systemic lupus erythematosis; T Thoracic; TB Tuberculosis 
common feature and present in only $18 \%$ (eight of 45 ) of patients in this review, comparable with a previous series reporting $17.9 \%$ (8). The white blood cell count is often normal in patients with cryptococcal disease including osteomyelitis, and this is confirmed in this review. The erythrocyte sedimentation rate can be elevated and of variable range. Neither are specific for cryptococcal skeletal infections as opposed to infections in other locations or due to other organisms.

The radiological evidence is usually indicative of osteomyelitis but, again, is not specific for a fungal etiology. Common findings include a lytic lesion eroding the inner and outer tables but without surrounding sclerosis or periosteal changes and an overlying soft tissue mass (6). All of the patients in this series had a lytic bone lesion on plain film. Given the nonspecific radiological findings, as well as the nonspecific clinical and laboratory picture, the diagnosis of cryptococcosis is often delayed or not made ante-mortem (19). The differential diagnosis includes other mycotic infections as well as bacterial infections such as those due to Staphylococcus aureus and less common bacteria including brucella, actinomyces, mycobacterium tuberculosis and atypical mycobacteria. Neoplastic lesions ranging from primary osteogenic sarcoma and myeloma to metastatic carcinoma can also mimic the radiological picture. This type of osteolytic skull lesion can also be seen with parietal foramina, dermoid cysts, hemangiomas and meningoceles (3). Several of the patients in this series were treated for other diagnoses such as bacterial osteomyelitis (20), neoplasm (21) and tuberculosis (22) before the correct diagnosis was made.

Temporal bone involvement with cryptococcal disease has been documented in only four cases from 1956 until the present (23-26), with this case making the total five. Each of the previously described cases was associated with cryptococcal meningitis with involvement of the nerves in the internal auditory canal. The case presented, to our knowledge, is the first report of isolated temporal bone involvement with $\mathrm{C}$ neoformans.

In our series, the diagnosis of skeletal cryptococcosis was made by a number of techniques but generally involved examination of lesion material whether from aspiration, incision and drainage, draining sinuses or open biopsy. The sample should be sent for smear, culture and histological examination. Disseminated disease should be sought in all patients with any form of cryptococcosis, whether the patient is immunocompetent or immunocompromised. The seemingly 'normal' immunocompetent host may not always be so, as is discussed below. A relevant examination for disseminated cryptococcal infection includes a chest x-ray; lumbar puncture for India ink staining, antigen testing and culture; urine cultures; blood culture; sputum stain and culture; and skin lesion cultures if applicable (27). Francisco et al (28) present a case of a febrile woman with lymphoma in whom an ante-mortem diagnosis of disseminated cryptococcal infection was made with direct examination and culture of a bone marrow aspiration and biopsy. They suggest that a bone marrow examination be performed in high risk patients with an obscure febrile illness. Detection of cryptococcal antigen in serum should also be performed given its high sensitivity and specificity (18). However, because serum cryptococcal antibodies are present in only $30 \%$ to $40 \%$ of patients, this latter test is of limited value (27). Despite availability of the above-mentioned investigations, it is evident in some case reports that the burden of cryptococcus can be greater than suspected clinically $(2,19)$.

Once cryptococcosis has been diagnosed, a decision regarding appropriate and effective therapy must be made. Because the distinction between disseminated and local disease is often quite difficult and since the majority of skeletal cryptococcal infections probably result from hematogenous spread from the lungs, it is generally felt that all patients with skeletal cryptococcosis warrant some form of systemic therapy, and that the role of surgery is to lessen the infectious burden and prevent leptomeningeal involvement $(6,18)$. Some authors, however, suggest that surgical debridement alone may suffice in some cases of isolated skeletal cryptococcosis (7). Before the introduction of amphotericin in 1956, there were case reports of skeletal cryptococcosis with various clinical courses, ranging from spontaneous resolution to resolution with curettage to resolution with roentgen treatment and oral potassium iodide and to death (5). From the cases reviewed, it is obvious that a large variety of therapies have been used with success. The most common therapy for isolated skeletal disease has been amphotericin alone or combined with surgical debridement; however, in some cases surgery alone, 5FC (flucytosine) alone or a combination of systemic chemotherapy was used. Although there have been a few case reports of $5 \mathrm{FC}$ monotherapy $(4,5,29)$ there have also been case reports of resistant organisms developing. Therefore, if used, this agent should be used only in combination with another antifungal (30).

In reviewing the outcome of these 45 cases, it appears that only four died as a result of their disease: one with eventual widespread dissemination occurring months after the presentation of isolated skeletal disease was unrecognized (31); one with significant comorbid diseases (19); and two with perioperative complications related to debridement and biopsy $(32,33)$. The other 41 had a variable follow-up, with the majority having radiological and clinical improvement.

An attractive alternative form of therapy for cryptococcosis may be the oral azoles, given their good oral bioavailability and reported success in treatment of other forms of cryptococcosis. The majority of studies of the azoles in cryptococcal disease have focused on management of cryptococcal meningitis in AIDS patients. A recent trial with this patient population using primary therapy with fluconazole or with amphotericin B showed that both were equally efficacious (34) although other reports have not reached similar conclusions (35), and further trials are required to answer this question. There have been no reported cases of isolated skeletal cryptococcosis occurring in association with AIDS or positive HIV serology. This review found two other case reports of azole use in cryptococcal skeletal infections $(36,37)$. A note of caution needs to be made regarding the possibility of the development of azole resistance (38).

There remains significant uncertainty regarding the dose and duration of treatment as well as the means of assessing 
treatment efficacy when the only disease is isolated skeletal infection. Efficacy of therapy is often judged radiologically because many patients do not have systemic symptoms or other laboratory abnormalities to follow. All patients with any form of cryptococcal infection must be followed given the propensity of this organism to relapse as well as to cause chronic infections, especially in immunocompromised hosts. Disseminated disease must be excluded in all patients, both immunocompromised and immunocompetent, and if present, must be treated.

The treatment decisions referred to above rely on the clinician being able to distinguish between immunocompetent and immunocompromised hosts. The classical immunocompromise described in association with skeletal cryptococcosis involves abnormalities of cellular immunity such as those seen with lymphoma, leukemia, sarcoidosis and long term steroid use. It has been suggested in previous reports that approximately half of patients with any form of cryptococcosis will have an underlying disease or are receiving a therapy that affects cell mediated immunity (27). Table 2 summarizes the predisposing conditions noted in the case reports reviewed. There has been only one other report of skeletal cryptococcosis being associated with chronic hepatitis (21), which represented our patient's only other medical abnormality aside from CD4 lymphopenia, which in itself probably represents his predisposing condition and is probably not related to the hepatitis $B$ infection (39-41). There have been no reported cases of isolated skeletal cryptococcosis occurring in association with AIDS or positive HIV serology.

Seemingly immunocompetent patients may be subclinically immunocompromised as in the present case as well as others in this review. Schimpff and Bennett (42) examined abnormalities of cell mediated immunity in patients with cryptococcal infections. Seemingly 'immunocompetent' patients who had been cured of cryptococcal infections for at least a year had subtle but reproducible abnormalities in skin tests, lymphocyte migration inhibition and lymphocyte transformation compared with controls. Similar findings have been found by other investigators (43). However, specific studies of immunological function are not commonly recorded in patients with cryptococcal infection. In this review, only 11 patients had some laboratory investigation for cell mediated immunity abnormalities. The tests performed were not uniform and included delayed type hypersensitivity skin testing, rosette formation, lymphocyte response to mitogens, phytohemagglutinin transformation and interleukin-2 quantification. Only two other patients besides the one we report had $\mathrm{T}$ cell quantification $(44,45)$. Fifty-six per cent ( 25 of 45 ) of patients had no obvious predisposing factor for this infection and on clinical grounds were 'immunocompetent'. Of these 25 patients, eight had laboratory investigations and $75 \%$ (six of eight) were found to have abnormalities or cell mediated immunity. This makes us question whether patients we assume are immunocompetent may have subtle, persistent or transient immunological defects that render them immunocompromised and thus at risk for the establishment of such infections.
TABLE 2

Predisposing factors among 45 cases of isolated skeletal cryptococcosis

\begin{tabular}{lc}
\hline Predisposing factor(s) & Cases \\
\hline None noted & 25 \\
Sarcoidosis \pm steroids & 8 \\
Diabetes mellitus & 4 \\
Cancer & 3 \\
?Sarcoidosis on basis of described CXR & 2 \\
Diabetes mellitus/sarcoidosis/steroids & 1 \\
Systemic lupus erythematosus/steroids & 1 \\
Trauma & 1 \\
\hline
\end{tabular}

CXR Chest x-ray

It is for the above reasons that an examination of cell mediated immunity is reasonable in all patients with cryptococcosis. It is difficult to recommend specific tests or panels of studies for assessment of cell mediated immunity given that many have variable specificity and sensitivity. However, evaluation of lymphocyte subsets including counts and stimulation studies are an important objective evaluating tool (46). Because absolute CD4 counts are fairly standardized and more easily available, they will undoubtedly be employed more often in future (46).

\section{SUMMARY}

We present a case of isolated temporal bone cryptococcosis in a patient with chronic hepatitis B and idiopathic CD4 lymphopenia who was treated successfully with surgical debridement and oral fluconazole. We also summarize the reported cases of isolated skeletal cryptococcosis in the English literature over the past 29 years. Our review suggests that $62 \%$ of patients have single site involvement, with the most common sites affected being the vertebrae, ribs, tibia and femur. Fortyfour per cent of patients had obvious predisposing factors putting them at risk of this infection. Of those who did not and were investigated, $75 \%$ were found to have laboratory abnormalities of cell mediated immunity, suggesting that all patients with cryptococcosis should be investigated for evidence of immune dysfunction. Although no therapeutic regimen is standard, the most commonly employed is systemic amphotericin or a combination of local surgery and amphotericin.

ACKNOWLEDGEMENTS: We acknowledge the capable assistance of the Microbiology Laboratory at the University of Alberta Hospitals and the National Center of Human Mycotic Diseases in Edmonton, Alberta.

\section{REFERENCES}

1. Kerkering TM, Duma RJ, Shadomy S. The evolution of pulmonary cryptococcosis. Ann Intern Med 1981;94:611-90.

2. Lewis JL, Rabinovich S. The wide spectrum of cryptococcal infections. Am J Med 1972;53:315-22.

3. Galloway DC, Schochet SS. Cryptococcal skull granuloma. J Neurosurg 1981;54:690-2.

4. Nottebart HC, McGehee RF, Utz JPL. Cryptococcus neoformans osteomeylitis: case report of two patients. Sabouraudia 1974;12:127-32. 
5. Collins VP. Bone involvement in cryptococcus (torulosis). Am J Roentgenol 1950;63:102-12.

6. Armonda RA, Fleckenstein JM, Brandvold B, Ondra SL. Cryptococcal skull infection: a case report with review of the literature. Neurosurgery 1993;32:1034-6.

7. Chelboun J, Nade S. Skeletal cryptococcosis. J Bone Joint Surg 1977;59A:509-14.

8. Behrman RE, Masci JR, Nicholas P. Cryptococcal skeletal infections: case report and review. Rev Infect Dis 1990;12:181-90.

9. Meredith HC, John JR, Rogers CI, Gooneratne N, Reutner A. Case report 89. Skeletal Radiol 1979;4:53-5.

10. Chou MY, Loeh CS, Liang PL, Armstrong D. Osseous cryptococcosis. Chin Med J (Engl) 1978;4:226-73.

11. Glynn MJ, Duckworth G, Ridge JA, Grange WJ, Gibbs DD. Cryptococcal spondylitis: solitary infective bone lesions are not always tuberculous. Br J Rheumatol 1994;33:1085-6.

12. Kuaity J, Lewis FB. Cryptococcosis presenting as an osteolytic rib lesion. Minn Med 1968;51:1727-30.

13. Reeves DL. Cryptococcus (torula) granuloma of the skull. J Neurosurg 1967;27:70-2.

14. Chand K, Lall KS. Cryptococcosis (torulosis, European blastomycosis) of the knee joint. A case report with review of the literature. Acta Orthop Scand 1976;47:432-5.

15. Dounis E, Giamarellou H, Peppas TH, Sfikakis P. Skull, patella, and thigh cryptococcosis after a crashing injury of the temporal bone. J Chemother 1991;3:130-3.

16. Gosling HR, Gilmer WS. Skeletal cryptococcosis (torulosis). J Bone Joint Surg Am 1956;38A:660-8.

17. Gurevitz O, Goldschmied-Reuven A, Block C, Kopolovic J, Farfel Z, Hassin D. Cryptococcus neoformans vertebral osteomyelitis. J Med Vet Mycol 1994;32:315-8.

18. Fialk MA, Marcove RC, Armstrong D. Cryptococcal bone disease: a manifestation of disseminated cryptococcosis. Clin Orthop 1981;158:219-23.

19. Kromminga R, Staib F, Thalmann U, et al. Osteomyelitis due to Cryptococcus neoformans in advanced age: case report and review of literature. Mycoses 1990;33:157-66.

20. Davey JKA. Cryptococcosis of bone. Cent Afr J Med 1969;15:78-9.

21. Matsushita T, Suzuki K. Spastic paraparesis due to cryptococcal osteomyelitis. A case report. Clin Orthop 1985;196:279-84.

22. Ong TH, Prathap K. Localized osseous involvement in cryptococcosis: case report and review of the literature. Aust NZ J Surg 1970;40:186-90.

23. Igarahi M, Weber SC, Alford BR, Coats AC, Jerger J. Temporal bone findings in cryptococcal meningitis. Arch Otolaryngol 1975;101:577-83.

24. Harada T, Sando I, Myers EN. Temporal bone histopathology in deafness due to cryptococcal meningitis. Ann Otol 1979;88:630-6.

25. McGill TJI. Mycotic infection of the temporal bone. Arch Otolaryngol 1978; 104:140-4.

26. Cash JB, Goodman NL. Cryptococcal infection of the temporal bone. Diagn Microbiol Infect Dis 1983;1:257-60.

27. Hawkins C, Armstrong D. Fungal infections in the immunocompromised host. Clin Haematol 1984;13:599-622.

28. Francisco R, Durant JR, Gams RA. Demonstration of Cryptococcus neoformans in a stained bone marrow specimen. Arch Intern Med 1977;137:688-90.

29. Vandevelde AG, Mauceri AA, Johnson JE. 5-Fluorocytosine in the treatment of mycotic infections. Ann Intern Med 1972;77:43-51.

30. Bennett JE. Flucytosine. Ann Intern Med 1977;86:319-22.

31. Plummer NS, Symers WE, Winner HI. Sarcoidosis in identical twins, with torulosis as a complication in one case. BMJ 1957;ii:599-603.

32. Balasubramaniam P, Silva JF. Case of cryptococcosis of spine. BMJ 1973;ii:27-8.

33. Reinig JW, Hungerford GD, Mohrmann ME, Vera CL. Case report 268. Diagnosis: cryptococcal osteomyelitis of the calvaria. Skeletal Radiol 1984;11:221-3.

34. Saag MS, Powderly WG, Cloud GA, et al. Comparison of amphotericin B with fluconazole in the treatment of acute AIDS-associated cryptococcal meningitis. N Engl J Med 1992;326:83-9.

35. Larson RA, Leal ME, Chan LC. Fluconazole compared with amphotericin B plus flucytosine for cryptococcal meningitis in
AIDS. Ann Intern Med 1990;113:183-7.

36. Gould PR, Gould IM. Cryptococcosis in Zimbabwe. Trans R Soc Trop Med Hyg 1985;79:67-9.

37. Ueda Y, Roessner A, Edel G, Wuisman P, Erlemann R, Bocker W. Case report 699. Primary localized skeletal cryptococcosis (torulosis) of the right tibia at its proximal end. Skeletal Radiol 1992;21:117-9.

38. Birley HDL, Johnson EM, McDonald P, Parry C, Carey PB, Warnock DW. Azole drug resistance as a cause of clinical relapse in AIDS patients with cryptococcal meningitis. Int J STD AIDS 1995;6:353-5.

39. Kim SA, Lee SI, Choi IH, et al. Circulating immune complexes and cell mediated immunity in patients with hepatitis B virus associated liver disease. Yonsei Med J 1990;31:347-58.

40. Alexander GJM, Nouri-Aria KT, Eddleston ALWF, Williams R. Contrasting relations between suppressor-cell function and suppressor-cell number in chronic liver disease. Lancet $1983 ; 1: 1292-3$.

41. Thomas HC, Brown D, Routhier G, et al. Inducer and suppressor T-cells in hepatitis B virus induced liver disease. Hepatology 1982;2:202-4.

42. Schimpff SC, Bennett JE. Abnormalities in cell-mediated immunity in patients with Cryptococcus neoformans infection. J Allergy Clin Immunol 1975;55:430-41.

43. Diamond RD, Bennett JE. Disseminated cryptococcosis in man: decreased lymphocyte transformation in response to Cryptococcus neoformans. J Infect Dis 1973;127:694.

44. Heenan PJ, Dawkins RL. Cryptococcosis with multiple squamous cell tumors associated with a T-cell defect. Cancer 1981;47:291-5.

45. Sorenson RU, Boehm KD, Kaplan D, Berger M. Cryptococcal osteomyelitis and cellular immunodeficiency associated with interleukin-2 deficiency. J Pediatr 1992;121:873-9.

46. Mandel GL, Bennett JE, Dolin R. Principles and Practice of Infectious Diseases, 4 th edn. New York: Churchill Livingstone, 1995:138-9.

47. Hickie JB, Walker T. Cryptococcosis (torulosis): some problems in diagnosis and management. Australas Ann Med 1964;13:229-39.

48. Abdul-Karim FW, Pathria MN, Heller JG, Sorensen RU. Case report 664. Cryptococcus neoformans osteomyelitis. Skeletal Radiol 1991;20:227-9.

49. Govender S, Ganpath V, Charles RW, Cooper K. Localized osseous cryptococcal infection. Report of 2 cases. Acta Ortho Scand 1988;59:720-2.

50. Woolfitt R, Park HM, Greene M. Localized cryptococcal osteomyelitis. Radiology 1976;120:290.

51. Magid D, Smith B. Cryptococcus neoformans osteomyelitis of the clavicle. Orthopedics 1992;15:1068-70.

52. Durie EB, MacDonald L. Cryptococcosis (torulosis) of bone. J Bone Joint Surg 1961;43B:68-70.

53. Morris E, Wolinsky E. Localized osseous cryptococcosis. A case report. J Bone Joint Surg Am 1965;47A:1027-9.

54. Hammerschlag MR, Domingo J, Haller JO, Papayanopulos D. Cryptococcal osteomyelitis. Report of a case and a review of the literature. Clin Pediatr 1982;21:109-12.

55. Cowen NJ. Cryptococcosis of bone. Case report and review of the literature. Clin Orthop 1969;66:174-82.

56. Shaff MI, Berger JL, Green NE. Cryptococcal osteomyelitis, pulmonary sarcoidosis, and tuberculosis in a single patient. South Med J 1982;75:225-6.

57. Poliner JR, Wilkins EB, Fernald GW. Localized osseous cryptococcosis. J Pediatr 1979;94:597-9.

58. Ganjei P, Evans DA, Fischer ML. Diagnosis of cryptococcal osteomyelitis by fine needle aspiration cytology. A case report. Acta Cytol 1982;26:224-6.

59. Nathan CF. Cryptococcal osteomyelitis treated with 5-fluorocytosine. Am Rev Respir Dis 1974;110:78-81.

60. Burch KH, Fine G, Quinn EL, Eisses JF. Cryptococcus neoformans as a cause of lytic bone lesions. JAMA 1975;231:1057-9.

61. Amenta PS, Stead J, Kricun ME. Case report 226. Skeletal Radiol 1983;9:263-65.

62. Allcock EA. Torulosis. J Bone Joint Surg 1961;43B:71-6.

63. Pedraza MA. Cryptococcosis of bone. Case report. Ohio State Med J 1974;70:559-62.

64. Sommer AW, Christian JJ, Carabasi RJ, Paler RL, Johnson WC, Sunbury TR. Clinicopathologic conference. Texas State J Med 
1965;61:348-56.

65. Zach TL, Penn RG. Localized cryptococcal osteomyelitis in an immunocompetent host. Pediatr Infect Dis 1986;5:601-3.

66. Baldwin S, Stagno S, Odrezin GT, Kelly DR, Whitley RJ. Isolated Cryptococcus neoformans osteomyelitis in an imunocompetent child. Pediatr Infect Dis 1988;7:289-92.

67. Koshi G, Sudersanam D, Selvapandian AJ, Myers RM. Cryptococcosis "masquerading" as tuberculosis of the spine. Indian J Pathol Bacteriol 1964;7:264-71.

68. Rolston KVI, LeFrock JL, Berman AT, Bosacco SJ. Treatment of osseous cryptococcosis. Report of a case and review of the literature. Orthopedics 1982;5:1610-4.
69. Bryan CS. Vertebral osteomyelitis due to Cryptococcus neoformans. Case report. J Bone Joint Surg Am 1977;59A:275-67.

70. Bernard LA, Owens JC. Isolated cryptococcosis associated with Boeck's sarcoid. Report of a case treated with amphotericin B. Arch Intern Med 1960;106:101-11.

71. Levine AM, Meier P, Dorfman HD. Case report 329. Skeletal Radiol 1985;14:152-6.

72. Lie KW, Yu YL, Cheng IK, Woo E, Wong WT. Cryptococcal infection of the lumbar spine. J R Soc Med 1989;82:172-3.

73. Cure JK, Mirich DR. MR imaging in cryptococcal spondylitis. Am J Neuroradiol 1991;12:1111-2. 


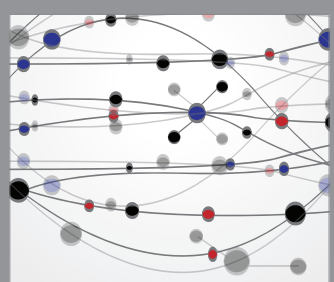

The Scientific World Journal
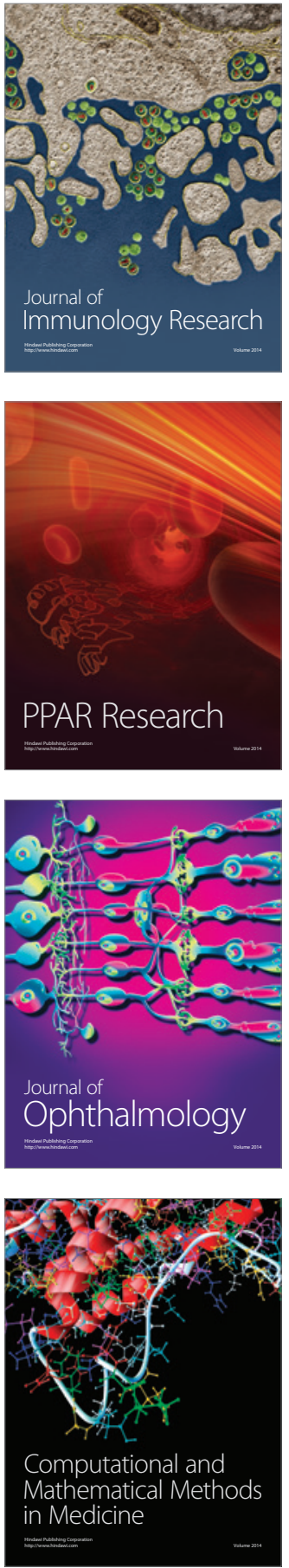

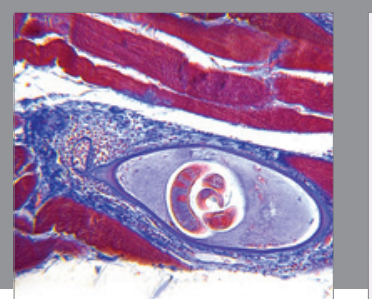

Gastroenterology Research and Practice

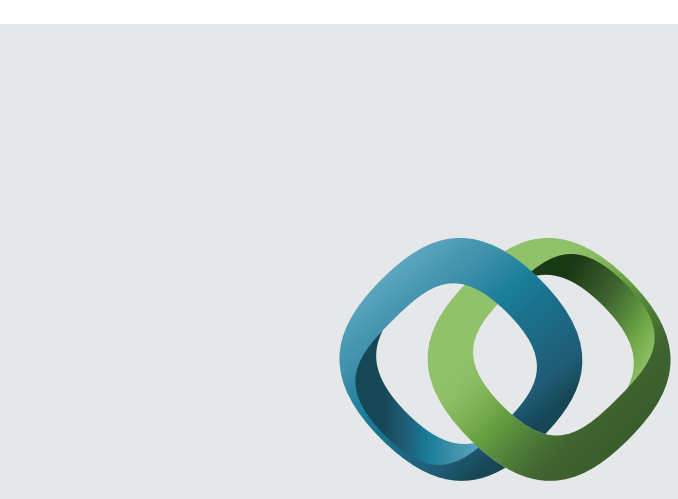

\section{Hindawi}

Submit your manuscripts at

http://www.hindawi.com
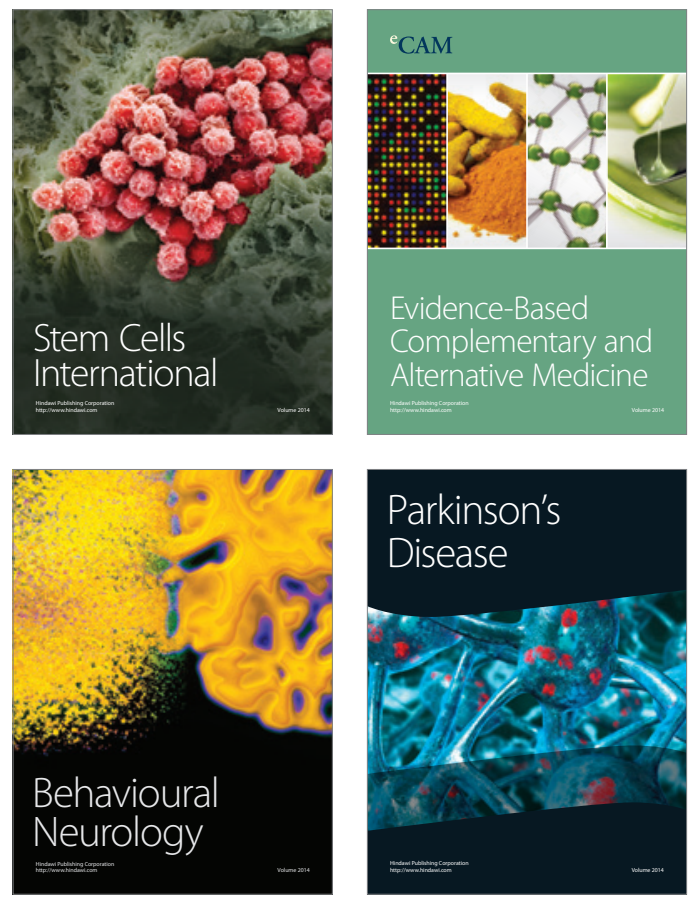
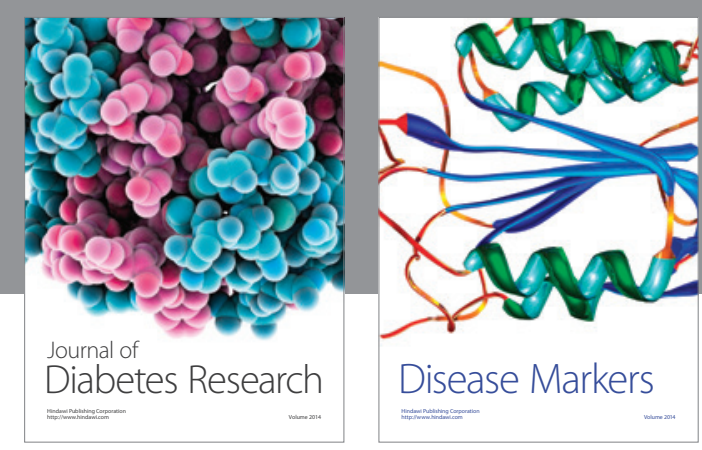

Disease Markers
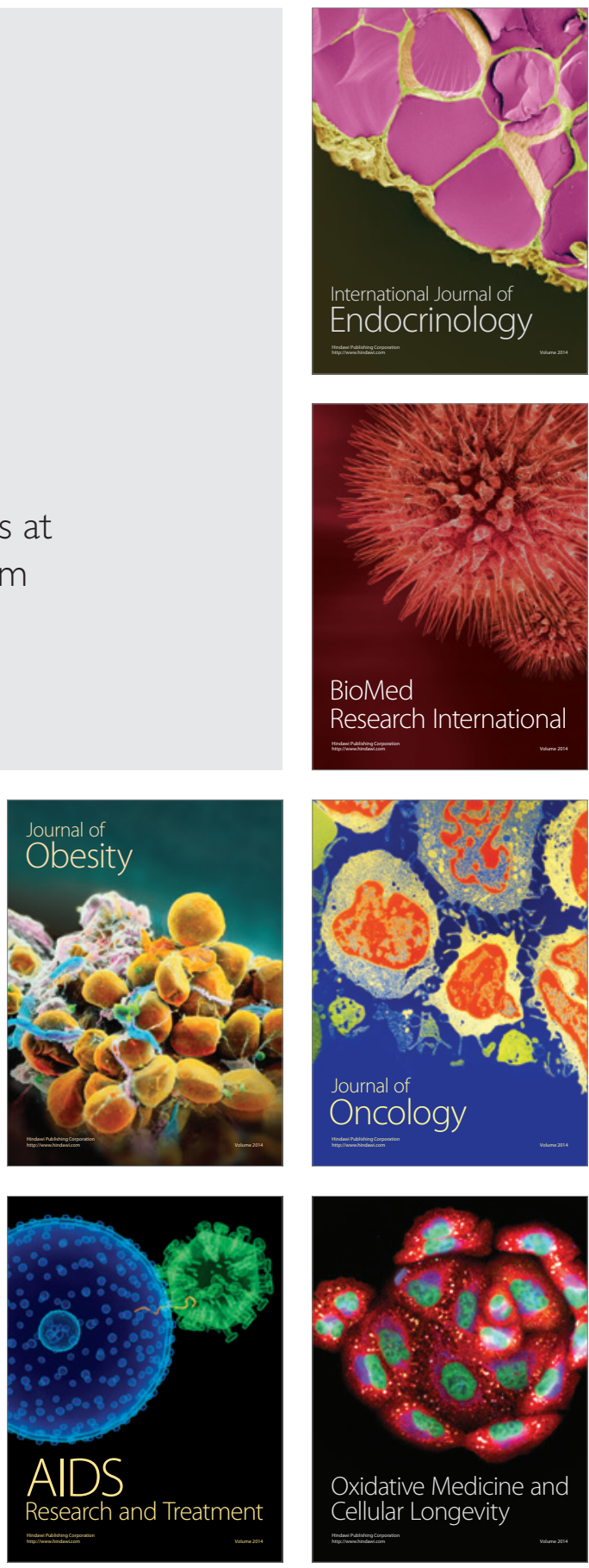